\title{
A FUNCTIONAL APPROACH TO MUNICIPAL POLICYMAKER DETERMINATIONS IN SECTION 1983
}

\author{
KAREN LOTT*
}

Debtors' prisons are alive and well in America despite being deemed unconstitutional. Indigent defendants often find themselves caught in a cycle of unconstitutional bail, fines, and fees that ultimately may land them in jail with no consideration of their indigency. These indigent defendants have a route to relief through Section 1983, which provides a federal forum for those plaintiffs deprived of federally protected rights by state actors. Unfortunately, awards of money damages, while possible, are often out of reach.

This article primarily addresses the notion of municipal policymaker determinations. In short, the plaintiff may pursue money damages against a municipality, but he often must show that the action which deprived him of his constitutional right was made by a municipal policymaker. An issue thus arises for the indigent defendant whose fate has been decreed by judicial order. For the defendant to hold the municipality liable, he would need to show that the municipal judge who issued the decree acted as a municipal policymaker. In making such policymaker determinations, courts look to state law. If the applicable state law defines a municipal judge as part of the state judiciary, then the judge cannot be a municipal policymaker. This formulaic determination often prevents the indigent plaintiff from connecting the unconstitutional judicial order to the municipality, which in turn prevents the plaintiff from receiving money damages from the city.

While at first glance the separation between a municipal judge and the municipality may seem like a fair disconnect in order to protect the independence of the local judiciary, the reality is that it may ignore the way in which some municipalities actually operate. To explain, local judges are often hired and fired by the city, and recent cases reveal the pressure that some cities put on judges to fund their own courts through fine and fee imposition. With this in mind, municipal judges may actually come to set municipal policy - and policymaker determinations should reflect that.

This article proposes a solution: a functional approach to policymaker determinations. Instead of simply relying on statutory definitions of judges, courts should look to the actual functions that the judge is performing. If the judge is acting under the municipality's authority and subject to the municipality's influence, then, in consideration of the judge's actual function within the municipality, he should be considered a policymaker for the locality. With this functional approach, plaintiffs would be able to pursue money damages and connect allegedly unconstitutional judicial orders to the corresponding responsible municipality.

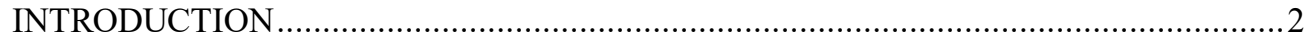

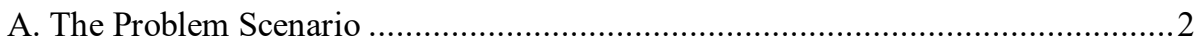

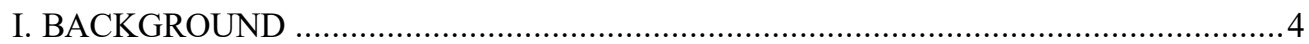

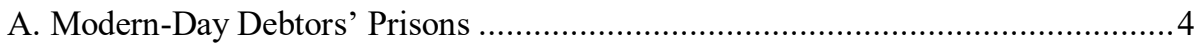

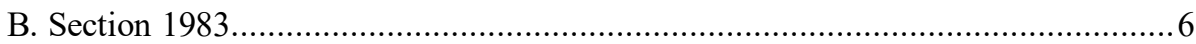

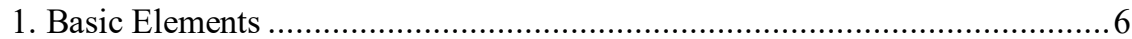

\footnotetext{
* J.D., Class of 2020, University of Mississippi School of Law. Thanks to Professor Cliff Johnson and the MacArthur Justice Clinic for their important work, which inspired this article. Also, thanks to Professor Matthew Hall for his thoughts and encouragement in completing this piece.
} 


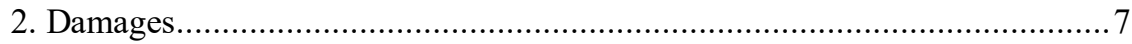

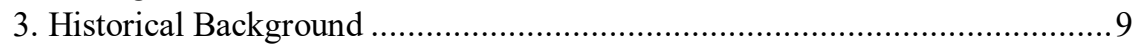

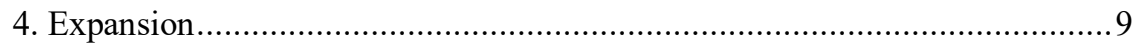

5. Retraction: Criticism and Immunity Defenses ....................................... 10

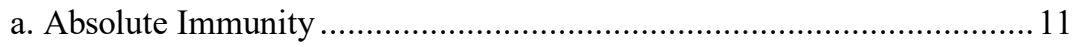

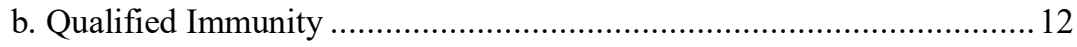

c. Judicial Immunity ........................................................................ 12

6. Municipal Liability/Monell ..................................................................... 13

a. Policymakers ................................................................................ 14

b. When a Municipal Judiciary is Influenced by the Local Executive

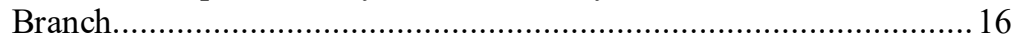

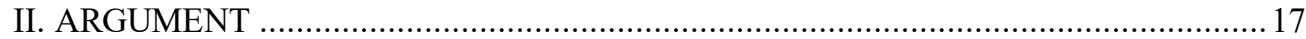

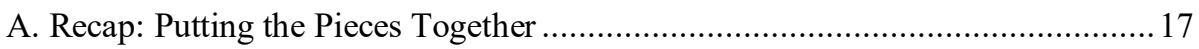

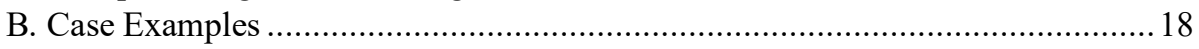

1. Judge Not Recognized as a Policymaker................................................ 18

2. Judge Recognized as Policymaker ........................................................220

C. A Better Solution? A Functional Approach ................................................. 21

1. Description ............................................................................... 21

2. Other Areas of Section 1983 Litigation that Employ a Functional Approach22

D. Limitations to a Functional Approach ..............................................................23

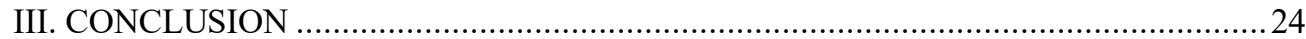

\section{INTRODUCTION}

\section{A. The Problem Scenario}

In Bearden v. Georgia, the United States Supreme Court made clear that a state may not imprison a person solely based on his inability to pay a fine. ${ }^{1}$ In Bearden, the Court held that before a defendant's probation is revoked for non-payment of a court-ordered fine, a reviewing court must inquire into that defendant's ability to pay. ${ }^{2}$ To do otherwise would be to punish him for his poverty; and yet, what can be considered debtors' prisons continue to crop up.

For example, imagine a scenario in which a judge sets bail, and the detained individual must come up with $\$ 500$. He is indigent and cannot pay. He remains in jail, though no determination of guilt or innocence has been made. His neighbor in the next cell also needs $\$ 500$ to meet bail, is able to do so, and is therefore quickly released to his family.

Imagine another scenario in which a municipality relies on fines and fees to keep its municipal court running. The municipal judge accordingly sets fee schedules for indigent defendants but hires a third-party probation service to oversee the collection of monies. The monthly

1461 U.S. 660, 674 (1983) (holding that the state may not imprison a person solely based on the poverty or inability of the individual to pay if he has shown bona fide efforts to do so).

$2 \quad I d$. 
payment, then, is $\$ 50$ - $\$ 35$ of which is allocated to so-called "probation services." ${ }^{\prime 3}$ In this way, a $\$ 250$ traffic ticket turns into an exorbitant expense payable over several months, and if the individual fails to make a single payment, the judge may order his incarceration. ${ }^{4}$

This time, imagine a teen mother who has a warrant out for her arrest for a misdemeanor, and the youth court judge overseeing her case prohibits the young mother from having custody of her child until she pays her court fees in full. ${ }^{5}$

These are not imagined scenarios at all. In fact, they are real situations in which indigent defendants' constitutional rights have been violated. What sort of relief might an individual in such a case expect?

Perhaps declaratory or injunctive relief may be sought, which ostensibly would subject the court to strict oversight or prevent it from continuing the unconstitutional practices. But what about the indigent defendant who has been sitting in jail for days and is unable to work or look for work, provide for his family, or prevent the loss of his vehicle or home after literally losing his liberty prior to any determination of culpability? Theoretically, an award of money damages for that plaintiff would be more appropriate, but this remedy is often difficult to realize.

Section 1983 of the United States Code is the road most plaintiffs travel to retrieve money damages for such constitutional violations. ${ }^{6}$ Put simply, a plaintiff may make a Section 1983 claim against a municipality to seek money damages when a state actor violates his or her federally protected rights. The key is that the claim must show the deprivation was caused by a municipal custom, policy, practice or decision made by a municipal policymaker.

In the above scenarios concerning bail and fines, the constitutional violations stemmed from a judicial order; it is only logical, then, to infer that the judge in each case acted as the municipal policymaker. But there's a catch in that judges enjoy immunity. As this article will show, courts often hold that a judge, in performing a judicial act, cannot also be a municipal policymaker. For this reason, plaintiffs typically cannot establish a nexus between an unconstitutional judicial order and the municipality or city that employs the judge who issued such order. Instead, the city can defend itself on grounds that its judges cannot be municipal policymakers, and because they are immune, the city also cannot be found liable. In this way, the city becomes complicit in and helps to perpetuate judicially decreed deprivations of constitutional rights. Plaintiffs thus face an uphill battle in getting the monetary relief that they deserve.

This dynamic is especially troubling in light of the ways in which the branches of government in some municipalities intersect. A city's mayor often appoints or hires municipal judges, whom the city pays as its employees and who, in some cases, are responsible for supplying the city with money from defendants' fines and fees. Such interplay between the local executive and judicial branches blurs crucial dividing lines, and a judge can seem more like an executive

3 Ray v. Judicial Corr. Servs., Inc. No. 2:12-CV-02819-RDP, 2017 WL 660842, at *2 (N.D. Ala. Feb. 17, 2017).

4 See, e.g., id. at *4-8.

5 See, e.g., City of Pearl Youth Court, MACARThur Justice Center (Oct. 26, 2017), https://www.macarthurjustice.org/case/5681-2/ [https://perma.cc/38KB-TCKV]; Radley Balko, Mississippi Judge Resigns After Barring Mother from Seeing Newborn Because of Unpaid Court Fees, THE WASHINGTON Post (Oct. 26, 2017, 11:23 AM), https://www.washingtonpost.com/news/the-watch/wp/2017/10/26/mississippi-judge-resigns-after-barring-motherfrom-seeing-newborn-because-of-unpaid-court-fees/?noredirect=on\&utm_term=.60c18e4b1426 [https://perma.cc/Y4T89XYG].

$6 \quad 42$ U.S.C. $\$ 1983(2019)$. 
officer and less like an independent, judicial officer.

When courts make determinations of whether a judge is a municipal policymaker, they should be able to consider how the functions of a particular municipality and of its judges might operate in tandem. While plaintiffs may make some arguments in line with painting the judge as a policymaker, a functional approach to determining who is a municipal policymaker is a more direct and fairer route.

In a case that requires a determination of whether a judge is either a municipal policymaker or state-level actor, a functional approach might shed light on that judge's actual duties. A functional approach would consider an individual judge's actual role and duties within the municipality, instead of relying on formulaic statutory interpretations, and it would uncover instances in which the municipality placed undue pressure on a judge to collect fines and fees. A functional approach would also help to uncover whether a municipality has been complicit in allowing unconstitutional bail, fine, and fee arrangements to exist or flourish. In turn, the responsible municipality, and not the judge, could be held liable; wronged plaintiffs could recover the damages to which they are rightfully entitled.

Other areas of Section 1983 litigation employ a functional approach, so it would not be a major stretch to extend the mode of analysis to policymaker determinations. More importantly, doing so would create an easier route to recovery for deserving plaintiffs from municipalities and would thus better serve the twin aims of Section 1983 litigation: compensation and deterrence. Moving forward, this article first provides background regarding modern-day debtors' prisons. It proceeds with an explanation of 42 U.S.C. $§ 1983$ 's major elements, its history, purposes and application. Then, discussion around immunity defenses, municipal liability, and the interconnectedness of local government branches will set the stage for the article's principal argument in favor of a more functional approach in the determination of who is a local policymaker. Thereafter, the article summarizes case examples that demonstrate the intersection of modern debtors' prisons, § 1983, judicial immunity and municipal liability. An argument as to the appropriateness of a functional approach to policymaker determinations foregrounds the final section of the article, where the author looks at the role of functional analyses in other areas of $\S 1983$ via hypothetical examples. Finally, the article ends with a review of perceived limitations inherent in a functional approach.

\section{BACKGROUND}

\section{A. Modern-Day Debtors' Prisons}

The traditional Dickensian portrayal of the debtor thrown in prison because he could not meet his obligations to a private creditor is generally an abhorred image of the past. And yet, debtors' prisons have not died; in fact, they've evolved over time. ${ }^{7}$ In the criminal justice system, indigent defendants are regularly jailed for their inability to pay fines or fees or meet bail, and the underlying transgression is often a misdemeanor offense. ${ }^{8}$

Take, for example, Roelif Carter, a veteran living off of disability and food stamps, who

7 See generally Christopher D. Hampson, The New American Debtors' Prisons, 44 AM. J. CRIM. L. 1 (2016) (analogizing historical debtors' prisons to the new debtors' prisons created by the criminal justice system itself).

8 See id. 
is incarcerated after failing to make a $\$ 100$ payment on an outstanding traffic ticket. ${ }^{9}$ Also consider Harriet Cleveland - a mother of three who was laid off from her job and jailed for over a month for not carrying vehicle insurance. ${ }^{10}$ She slept on the jail floor and was exposed to raw sewage from a leaking toilet in her cell. ${ }^{11}$ Both Carter and Cleveland spent time in jail for the "crime" of failing to pay fines associated with minor offenses.

Money bail can also violate a plaintiff's constitutional rights where a judge fails to consider his or her indigency. Imagine Perchelle Richardson, a teen who stole a cell phone and whose family could not afford the $\$ 200$ bond needed to secure her release. ${ }^{12}$ Instead, she missed 51 days of school to sit in jail, while a wealthy teen in the same circumstances would have easily met bail. ${ }^{13}$ These cases are not anomalies. ${ }^{14}$ In the past few years, many major media outlets ${ }^{15}$ and academics ${ }^{16}$ have

$9 \quad$ Id. at 4.

$10 \quad I d$.

$11 \quad I d$

12 Shima Baradaran Baughman, THE BaIL BoOK: A COMPREHENSIVE LOOK AT BAIL IN AMERICA'S CRIMINAL JUSTICE SYSTEM 159-60 (2018).

$13 \quad I d$.

14 See, e.g., Hampson, supra note 7, at 5 ("A 2015 class action lawsuit against the city of Austin, Texas, tallied about 900 jailed debtors within a twelve-month period. And by one count, the city of Houston jailed people for nonpayment of criminal justice debt in over 70,000 cases.").

15 See, e.g., Joseph Shapiro, Civil Rights Attorneys Sue Ferguson Over 'Debtors Prisons', NPR (Feb. 8, 2015, 9:03 PM), https://www.npr.org/sections/codeswitch/2015/02/08/384332798/civil-rights-attorneys-sue-ferguson-overdebtors-prisons [https://perma.cc/38PV-H752]; Sarah Stillman, Get Out of Jail, Inc., NEW YORKER (June 16, 2014), http://www.newyorker.com/magazine/2014/06/23/get-out-of-jail-inc [https://perma.cc/RRX3-8FJF] (discussing the prevalence of "offender-funded justice" in many states, particularly the South, and the troublesome ties between municipal courts and private companies, particularly probation companies, which impose various fees and administrative costs on indigent defendants on top of court-ordered fines and fees); The New Debtors' Prisons, The Economist, Nov. 16, 2013, at 46 (discussing the prevalence of imprisonment for nonpayment of debt, particularly in states with large prison populations); Last Week Tonight, Municipal Violations: Last Week Tonight with John Oliver, HBO (Mar. 22, 2015), available at https://www.youtube.com/watch?v=0UjpmT5noto [https://perma.cc/9ZVA-4QFH] (describing the mounting debt accrued for indigent individuals for failure to pay fines for minor traffic offenses, often resulting in incarceration, and the use of private companies in collecting these debts); The Colbert Report, The Word - Debt or Prison, COMEDY CENTRAL (June 11, 2014), http://www.cc.com/video-clips/m87g43/the-colbert-report-the-word---debt-or-prison [https://perma.cc/T48M4WB5] (explaining how the costs of public defenders, probation, parole supervision, electronic monitoring, and jail stays are shifted onto indigent defendants, which often leads to further incarceration); Alex Tabarrok, Debtor's Prison for Failure to Pay for Your Own Trial, MARginal Revolution (Apr. 18, 2012, 7:38 AM), https://marginalrevolution.com/ marginalrevolution/2012/04/debtors-prison-for-failure-to-pay-for-your-own-trial.html [https://perma.cc/M6LP-VQAH] (discussing the increased use of various costs, fees, and fines on indigent offenders by state and local governments to shore up budgets and the various consequences for failure to pay, such as ineligibility for public benefits, damaged credit reports, and exclusion from housing and employment).

16 See, e.g., Hampson, supra note 7; Sarah Dolisca Bellacicco, Note, Safe Haven No Longer: The Role of Georgia Courts and Private Probation Companies in Sustaining a De Facto Debtors' Prison System, 48 GA. L. REV. 221 (2014); Torie Atkinson, Note, A Fine Scheme. How Municipal Fines Become Crushing Debt in the Shadow of the New Debtors' Prisons, 51 HARV. C.R-C.L. L. REV. 189 (2016) (describing the shift to the reliance on municipal fines to address state and local budget shortfalls, the potential constitutionality issues associated with this system, the disparate effects on poor and minority communities, and options for reform); Adec Karakatsanis, Policing, Mass Imprisonment, and the Failure of American Lawyers, 128 HARV. L. REV. F. 253, 262-64 (2015) (providing accounts of individuals of color arrested and imprisoned for failure to pay debts, mostly from old tickets). 
covered this explosion of debtors' prisons and recounted the effects that such incarceration has on the indigent defendant.

The real outrage, however, is that debtors' prisons are unconstitutional, and the Supreme Court said so explicitly in Bearden v. Georgia. ${ }^{17}$ In Bearden, the Court held that if a defendant is unable to pay a fine, there must be both an inquiry as to his inability to pay and a consideration of alternative methods of punishment. ${ }^{18}$ The holding should have meant that indigent defendants would not be jailed simply for being poor, but such promise has not been realized. One commentator has pointed to the unique setup of the justice system as part of the problem. Indigent defendants feel pressure to plead guilty, and then, through court mechanisms such as probation services, drug testing, and fee arrangements, these defendants are kept in almost constant contact with the criminal justice system, making them more likely to miss a payment or receive additional fines. ${ }^{19}$ Whatever the underlying reason, the reality is that a modern day system of debtors' prisons has developed.

There are various ways to address the debtors' prison problem through meaningful reform within local legislative and judicial arenas. ${ }^{20}$ Indeed, some advocates look to legislatures and judiciaries to reform the underlying laws or court rules, ${ }^{21}$ while others have taken the approach of investigative journalist to make people aware of what is happening by way of exposé ${ }^{22}$ Still, some have chosen to initiate litigation not only as a means of securing damages for the wronged individuals, but also as a tool to achieve change through the court system itself. ${ }^{23}$ Clearly, then, there are different methods for attacking the debtors' prison problem, though this article explores only the litigation route.

Specifically, this article delves into the quintessential Section 1983 claim and its pitfalls with respect to the pursuit of money damages against a municipality for unconstitutional bail, fine, and fee practices. I offer an explanation of why it is often difficult to show that a judge is, in fact, a municipal policymaker, and propose a possible solution for the wronged plaintiff. To set the stage for this analysis, this article first furnishes some of the historical context of 42 U.S.C. $\S 1983$.

\section{B. Section 1983}

\section{Basic Elements}

Section 1983 litigation arises when a plaintiff makes a claim that he was deprived of his federally protected rights by a person acting under color of state law. ${ }^{24}$ In short, if a person acting

17461 U.S. 660,674 (1983).

$18 I d$. at 672.

19 Colin Reingold, Pretextual Sanctions, Contempt, and the Practical Limits of Bearden-Based Debtors' Prison Litigation, 21 MiCH. J. RACE \& L. 361, 362-63 (2016).

20 See, e.g., Hampson, supra note 7, at 44-46 (arguing for broader application of Bearden, beyond only those debtors unable to pay and when alternatives are available, to all criminal debts and imprisonment-for-debt claims and advocating for increased state protections for debtors).

$21 \quad I d$. at 13.

$22 \quad I d$. at 5.

23 Id. at $12-13$.

2442 U.S.C. $§ 1983$ states, “[e]very person who, under color of any statute, ordinance, regulation, custom, or usage, of any State or Territory or the District of Columbia, subjects, or causes to be subjected, any citizen of the United States or other person within the jurisdiction thereof to the deprivation of any rights, privileges, or immunities secured by 
under state or municipal authority deprives an individual of a constitutional right, then he may be liable for damages under Section 1983. Common claims include use of excessive force by an officer; employment concerns like hiring, firing, and discrimination; deliberate indifference to inmate needs or prison conditions; mishandling of issues in government schools or mental health facilities; and the unfair seizure of property. ${ }^{25}$

Since the law's enactment in 1871, case law has shaped the contours of Section 1983's role and scope. First, a plaintiff must prove the following elements in order to successfully state a Section 1983 claim: (1) a deprivation of a federally protected right, usually constitutional, that (2) was proximately caused (3) by an individual (4) acting under the color of state law. ${ }^{26}$ When making a Section 1983 claim, the plaintiff bears the burden of establishing each of these elements by a preponderance of the evidence. ${ }^{27}$ However simply stated, each of these elements may trigger a complicated analysis that puts a prospective plaintiff's goals further out of reach. Yet another challenge for plaintiffs in Section 1983 litigation is proving that money damages should be awarded even if a constitutional violation is found to have occurred.

\section{Damages}

Understanding how damages function under 42 U.S.C. $§ 1983$ lends additional insight with respect to the barriers plaintiffs face in establishing that they are entitled to monetary damages. To begin, Section 1983 allows for the full range of remedies - injunctive and declarative relief, as well as nominal, punitive ${ }^{28}$, and compensatory damages. ${ }^{29}$ The Supreme Court has singled out damages as an essential part of Section 1983 litigation because they achieve a twofold effect of compensating victims and deterring potential violators of constitutional rights. ${ }^{30}$

The standard for determining damages in Section 1983 litigation was derived from common law tort principles. ${ }^{31}$ In essence, a plaintiff may recover compensatory damages if he shows that a violation of his federally protected rights caused actual injury, which can include lost future earnings, medical expenses, and forgone wages. ${ }^{32}$ The Court has also made clear that pursuing monetary relief solely by claiming that constitutional rights are themselves valuable will not support an award of compensatory damages. ${ }^{33}$

\footnotetext{
the constitution and laws, shall be liable to the party injured in an action at law, suit in equity, or other proper proceeding for redress. ..."

25 See Martin A. Schwartz, Section 1983 Litigation Claims And Defenses § 1.01 (4th ed. 2018).

26 Martin A. Schwartz, Fundamentals of Section 1983 Litigation, 17 TOURO L. REV. 525, 527 (2001); MARY Massaron Et Al., Sword \& Shield: A Practical Approach to Section 1983 Litigation (4th ed. 2015).

27 MASSARON ET AL., supra note 26, at 7.

28 While punitive damages are generally available in Section 1983, they are not available in a Section 1983 suit against a municipal entity. See Smith v. Wade, 461 U.S. 30, 56 (1983) (allowing for punitive damages where defendant's conduct was motivated by evil intent or reckless indifference). But see City of Newport v. Fact Concerts, 453 U.S. 247,271 (1981) (holding punitive damages are not available in a suit against a municipality).

29 See SCHWARTZ, supra note 25 , at $\S 16.04$.

$30 \quad I d$. (quoting Owen v. City of Independence, 445 U.S. 622, 651 (1980)).

31 Id. (quoting Memphis Cmty. Sch. Dist. v. Stachura, 477 U.S. 299, 310 (1986)).

$32 \quad I d$.

$33 I d$. at $\S 16.05$ ("[D]amages based on the abstract 'value' or 'importance' of constitutional rights are not a permissible element of compensatory damages in [§ 1983] cases.” (quoting Memphis Cmty. Sch. Dist. v. Stachura, 477 U.S.
} 
In proving actual injury, the Court has held that plaintiffs may be awarded damages for pain and suffering, emotional distress, impairment of reputation, and humiliation. ${ }^{34}$ Claiming and proving emotional distress damages are, however, two very different things. To prove that he is entitled to damages for emotional distress, a plaintiff must present corroborated, detailed evidence-for example, medical testimony or witness testimony. ${ }^{35}$ Uncorroborated, conclusory allegations of emotional distress will not, by contrast, support a finding of damages. ${ }^{36}$ If a plaintiff successfully establishes that he is entitled to an award for emotional distress, a jury will determine the amount of damages owed. ${ }^{37}$

But another obstacle to proving actual injury - even for the plaintiff who can otherwise establish that he was deprived of a protected right - is the requirement that the damages incurred thereby be measurable. Without such a showing, a plaintiff will be entitled only to nominal damages for the violation of his rights. ${ }^{38}$ The Court has maintained that the deterrence goal of 42 U.S.C. $\S 1983$ will nevertheless be preserved in such cases, since the law enables plaintiffs to recover punitive damages without a showing of actual injury. ${ }^{39}$

The implication here is that responsible entities will still have to "pay up" through punitive damages even where compensatory damages are not awarded. However, punitive damages are not available as a remedy in suits against a municipal entity. ${ }^{40}$ This means that if a plaintiff cannot easily attach a provable dollar amount to the deprivation, the responsible municipality would essentially be off the hook with respect to damages, since punitive awards are not an option. Therefore, a constitutional deprivation could occur at the hands of a municipal entity, and yet, the deterrence goal of Section 1983 litigation could be completely circumvented. Therefore, plaintiffs who cannot tie constitutional violations to specific dollar amounts face yet another barrier that may undercut the purposes of 42 U.S.C. $\S 1983$ itself. $^{41}$

Evidently the Court only paid lip service to the importance of making monetary relief available in Section 1983 litigation, as the hurdle plaintiffs must overcome to recover damages

$299,310(1986)))$.

$34 \quad I d$. at $\S 16.04$ (“[C]ompensatory damages may include not only out-of-pocket loss and other monetary harms, but also such injuries as 'impairment of reputation ... personal humiliation, and mental anguish and suffering."” (quoting Memphis Cmty. Sch. Dist. V. Stachura, 477 U.S. 299, 307 (1986))).

35 Id. at $\S 16.05$.

$36 \quad I d$.

37 Id.

38 Carey v. Piphus, 435 U.S. 247, 248 (1978).

39 See SChwARTZ, supra note 25, at § 16.04 (citing Memphis Cmty. Sch. Dist. v. Stachura, 477 U.S. 299, 307 (1986)).

$40 \quad$ See City of Newport v. Fact Concerts, 453 U.S. 247, 271 (1981) (holding that punitive damages are not available against a municipality in a Section 1983 suit).

41 While this article focuses on how to show that a judge is a municipal policymaker when perpetuating unconstitutional bail, fine, and fee practices, it should be noted that there are inherent barriers for indigent plaintiffs who pursue money damages. The plaintiff's indigency may make it difficult to show an actual injury such as lost wages, and the standard for showing emotional distress damages is, in this author's view, quite stringent. Further, the decision is ultimately left to a jury which may be generally unsympathetic. In this way, even if a plaintiff $i$ s able to show that a judge is a municipal policymaker and the municipality should be responsible for his unconstitutional orders, the resulting money damages may not be very high. I query whether this limit is fair. Shouldn't that plaintiff's life and time be valuable even without a showing of actual damages lost, and aren't constitutional rights valuable to a free people in and of themselves? 
makes clear. The history of 42 U.S.C. $§ 1983$, which evinces at least some legislative intent to center the plaintiff, further underscores this disconnect.

\section{Historical Background}

The need for a federal civil rights statute arose in the aftermath of the Civil War due to the unchecked violence of the $\mathrm{Ku}$ Klux Klan. ${ }^{42}$ Federal officials were concerned that newly freed individuals and their supporters might be deprived of their federally protected rights by state officials acting under color of state law. ${ }^{43}$ Thus, Section 1 of the Civil Rights Act of 1871 (which would later become 42 U.S.C. $§ 1983$ ) was passed in order to hold state officials accountable through civil liability for their official acts. ${ }^{44}$ Despite the narrower problem of $\mathrm{Ku}$ Klux Klan violence that first spurred the need for this legislation, later Supreme Court decisions have expanded its application to provide redress for a wider scope of violations. ${ }^{45}$ Section 1983 is now the primary method by which a plaintiff can obtain relief for constitutional deprivation caused by a state actor. ${ }^{46}$ To be clear, Section 1983 does not provide a claim for relief in and of itself; instead, it acts as somewhat of a conduit for any claim that a federally protected right has been violated. ${ }^{47}$ For this reason, Section 1983 claims come in many different forms, and as more rights are protected at the federal level, more Section 1983 claims become possible.

\section{Expansion}

Section 1983 remained relatively unused until the Supreme Court decided Monroe v. Pape in 1961. There, the Court recognized that a Section 1983 claim, as a claim separate from any state law claim, provides a remedy regardless of whether a state law remedy is available. ${ }^{48}$ As more rights were incorporated against the states, more Section 1983 claims became viable. ${ }^{49}$ Then, during the height of Section 1983 expansion, the Supreme Court recognized the plaintiff-centric purposes of the legislation. The Court noted the major goals of the legislation as "compensation and deterrence" 50 and explained that the primary purpose of the post-Civil War civil rights statutes was

42 See Monroe v. Pape, 365 U.S. 167, 172-75 (1961) (summarizing the history of $\S 1983$ and quoting a letter President Grant wrote to Congress urging the passing of a bill to “ . . secure life, liberty, and property, and the enforcement of law in all parts of the United States.”); see generally SCHWARTZ, supra note 25, at $\S 1.03$.

43 Monroe, 365 U.S. at 172-75.

44 Id.; see also David M. Coriell, Note, The Transferred Immunity Trap: Misapplication of Section 1983 Immunities, 100 CORNELL L. REV. 985, 986 (2015).

45 See generally SCHWARTZ, supra note 25 , at $\S 1.03$.

$46 \quad I d$.

47 See SCHWARTZ, supra note 25 , at $\S 1.03$.

$48 \quad I d$.

49 Id.

50 Hardin v. Straub, 490 U.S. 536, 539 (1989). See also Wyatt v. Cole, 504 U.S. 158, 161 (1992) (affirming that the purpose of Section 1983 is to provide relief to victims and deter state actors from depriving people of their federallyguaranteed rights); Robertson v. Wegmann, 436 U.S. 584, 590-91 (1978) (finding compensation of injured persons and prevention of abuses of power to be the foundational policies of Section 1983); SCHWARTZ, supra note 25, at $\S 1.03$ (finding that the policies underlying Section 1983 include compensation for individuals when their federally-protected rights are violated and prevention of future violations). 
to afford plaintiffs a route to relief. ${ }^{51}$ Further, the court explained that the statute's language should be interpreted broadly. ${ }^{52}$ At the heart of this case law is recognition of the fact that plaintiffs wronged by state actors deserve relief.

Certain judges have extolled the benefits of Section 1983 by recognizing it as the mechanism that has ensured some of the country's most significant constitutional decisions to date. ${ }^{53}$ Cases such as Roe v. Wade, Brown v. Board of Education, Reynolds v. Sims, and Obergefell v. Hodges all were initiated under 42 U.S.C. $\S 1983,{ }^{54}$ which one D.C. Circuit judge described as ". . . the workhorse of civil rights litigation." ${ }^{5}$

In sum, Section 1983 was originally needed to combat the gross constitutional deprivations taking place in the Reconstruction-Era South, but its role was in no way limited to that function. The Supreme Court, in many landmark decisions, has emphasized that Section 1983 has rightly carved out its place as a hallmark of civil rights litigation. The legislation was created to allow plaintiffs wronged by state actors to receive monetary and injunctive relief and to deter constitutional wrongdoers.

\section{Retraction: Criticism and Immunity Defenses}

The expansion of Section 1983 is not, however, without its critics on the Court. Justices Powell and Scalia believed that the expansion violated the law's limited original purpose. ${ }^{56}$ Others have lamented it for increasing the likelihood for a state common law tort action to be paraded as a federal claim, ${ }^{57}$ while some justices have labeled it an intrusion on states' rights $^{58}$ and a strain on federal courts. ${ }^{59}$ One possible consequence of such criticism is that, while Section 1983 does provide several avenues of relief, the Court has also accepted corresponding defenses, especially

51 SCHWARTZ, supra note 25 , at $§ 1.03$ ("The statute was thus enacted in order to create a federal remedy that 'protects the people from unconstitutional action under color of state law whether that action be executive, legislative, or judicial."” (citing Mitchum v. Foster, 407 U.S. 225, 242 (1972))).

52 Monell v. Dep’t of Social Servs., 436 U.S. 658, 685 (1978); SCHWARTZ, supra note 25, at § 1.03.

53 Harry A. Blackmun, Section 1983 and Federal Protection of Individual Rights-Will the Statute Remain Alive or Fade Away, 60 N.Y.U. L. REV. 1, 1-2 (1985). United States Supreme Court Justice Harry A. Blackmun wrote this entire journal article examining the history of Section 1983 and explaining the importance of its symbolic and practical applications in today's modern setting. In the article, Justice Blackmun also addresses Supreme Court cases that have made it more difficult for plaintiffs to get relief and that have expanded immunities to cloak state entities with a veil of protection. He ultimately queries whether the statute will remain a robust way to check those actors who would trample on individual liberties. Finally, he concludes by stating, "[w]hatever is the fate of Section 1983 in the future, I do hope that it survives both as a symbol and as a working mechanism for all of us to protect the constitutional liberties we treasure."

54 SCHWARTZ, supra note 25, at $§ 1.01$.

55 Id. (quoting Morgan v. Dist. of Columbia, 824 F.2d 1049, 1056 (D.C. Cir. 1987)).

56 See Crawford-El v. Britton, 523 U.S. 574, 611 (1998) (Scalia, J., dissenting) ("The $\S 1983$ that the Court created in 1961 bears scant resemblance to what Congress enacted almost a century earlier."); Parratt v. Taylor, 451 U.S. 527, 553 (1981) (Powell, J., concurring) ("In sum, it seems evident that the reasoning and decision of the Court today, even if viewed as compatible with our precedents, create new uncertainties as well as invitations to litigate under a statute [§ 1983] that already has burst its historical bounds."); SCHWARTZ, supra note 25, at $\S 1.03$.

57 See SCHWARTZ, supra note 25 , at $\S 1.03$.

$58 \quad I d$

$59 \quad I d$ 
immunity defenses.

The text of Section 1983 does not explicitly mention immunities, ${ }^{60}$ but they are traditionally recognized at common law and have been successfully deployed as defenses. ${ }^{61}$ Such immunities primarily serve the two-fold purpose of (1) allowing public officers to focus on their jobs and not on time consuming litigation and (2) preserving public officials' independent discretion so that the constant fear of potential litigation does not cause poor decision-making. ${ }^{62}$ When hearing Section 1983 cases, judges may "read in" any common law immunity available at the time the law was enacted as long as it is consistent with the legislation. ${ }^{63}$ The next sections of this article further describe the oft-used immunity defenses.

\section{a. Absolute Immunity}

Absolute immunity shields certain actors from liability even for acts that are unconstitutional or outside the bounds of law. ${ }^{64}$ Courts take a functional approach to determining whether a defendant will be absolutely immune from liability in a Section 1983 suit: instead of relying solely on a public official's job title, courts look instead to both the nature of the job function and the ways, if any, in which subjecting the public official to the possibility of litigation might affect performance of that job function. ${ }^{65}$ With this in mind, the Court has recognized absolute immunity for legislators acting in a legislative capacity, ${ }^{66}$ judges performing judicial acts, ${ }^{67}$ and prosecutors acting as advocates ${ }^{68}$ as opposed to investigators. ${ }^{69}$

Some courts have also extended absolute immunity to actors performing judicially oriented functions and prosecutorial functions, such as court reporters, parole officers acting in a judicial capacity, grand jurors, or social workers bringing suit on behalf of a child abuse victim. ${ }^{70}$ Some commentators have criticized this extension of absolute immunity, claiming that the legislative history does not support such a defense and that immunity creates an extra barrier for the wronged plaintiff to get relief. ${ }^{71}$

\footnotetext{
6042 U.S.C. 1983 (2019).

61 See Margaret Z. Johns, A Black Robe Is Not a Big Tent: The Improper Expansion of Absolute Judicial Immunity to Non-Judges in Civil-Rights Cases, 59 SMU L. REV. 265, 269 (2006).

62 MASSARON ET AL., supra note 26, at 504-24.

$63 \quad I d$.

64 SCHWARTZ, supra note 25 , at $\S 9.02$.

65 MASSARON ET AL., supra note 26, at 504-06.

66 SCHWARTZ, supra note 25, at $\$ 9.02$. For example, a plaintiff cannot receive money damages if he sues a legislator for signing on to what the plaintiff believes to be an unconstitutional law. The legislator is absolutely immune.

67 Id. In other words, a plaintiff may not sue a judge and receive money damages for making a "bad" decision. The judge is absolutely immune.

68 Id. For example, a plaintiff may not sue a prosecutor because the prosecutor does his job in prosecuting a case. The prosecutor is absolutely immune in that role.

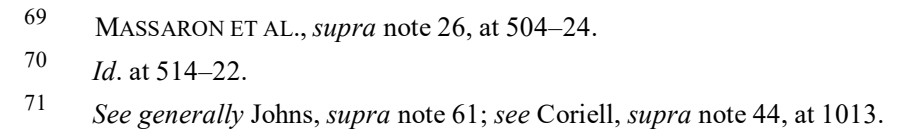




\section{b. Qualified Immunity}

Another type of immunity which is more limited in its scope is qualified immunity. If a government official does not qualify for absolute immunity from personal liability, qualified immunity may still shield them. First, to receive qualified immunity, the government actor must be acting under their own discretion. ${ }^{72}$ Second, the government official's unconstitutional actions must meet the reasonable person standard. ${ }^{73}$ In other words, if an officer uses their discretion to violate a person's constitutional or statutory rights, but an objective reasonable person would not have known that these actions were unconstitutional, then the officer may assert qualified immunity as a defense. ${ }^{74}$ While both absolute immunity and qualified immunity pose potential barriers for harmed plaintiffs to recover money damages, judicial immunity makes litigation concerning bail, fines, and fees especially difficult.

\section{c. Judicial Immunity}

Judges are absolutely immune from Section 1983 claims for damages arising from their judicial acts. ${ }^{75}$ There are only two limits to this immunity: if the judge acts completely without jurisdiction, or if the act is not judicial, then absolute judicial immunity is not available as a defense. ${ }^{76}$ By extension, judges are also not immune from suits arising from conduct undertaken outside of their official roles. Still, broad judicial immunity is rooted in the common law and its long existence has been justified based on the potentially chilling effect that liability for judicial acts could have on independent decision making and the availability of other remedies. ${ }^{77}$

Usually, if a judge performs an act that is not judicial, the act is labeled "administrative." Administrative acts have included tasks related to supervising a court employee, such as hiring, firing, and demoting, ${ }^{78}$ and most importantly, acting as an administrator of a juvenile detention center or of a probation service. ${ }^{79}$ For claims arising out of what is presumed to be a judge's administrative act, a judge may assert only qualified immunity. ${ }^{80}$

Aside from these limited exceptions - a judge performing an administrative task, or a judge acting completely outside of their role-judges have broad protection from incurring liability in a suit. For this reason, if a defendant experiences a constitutional deprivation due to a judicial order, he cannot simply sue the judge. The defendant turned plaintiff would instead have to find another responsible entity to sue for relief. In cases concerning unconstitutional bail, fines, and fees, the plaintiff may attempt to sue the municipality that employs the judge. The next section of this

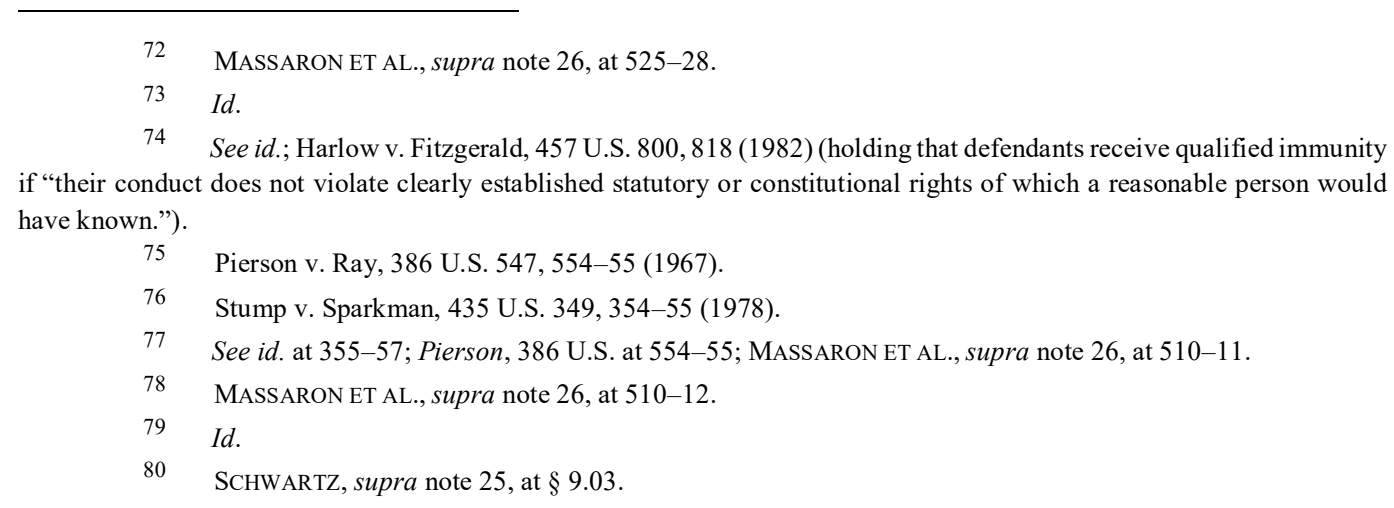


article describes how to make a Section 1983 claim against a municipality.

\section{Municipal Liability/Monell}

For purposes of this article, the most significant expansion of Section 1983 has been the Supreme Court's decision to recognize a municipality as a "person" as defined in the statute. ${ }^{81}$ In this way, a plaintiff who has been wronged by excessive bail, fines, or fees can pursue action against the responsible city or policymaker. In Monell v. New York City Department of Social Services, the Supreme Court held that a municipality may be a "person" in the context of Section $1983 .{ }^{82}$ The municipality will not, however, be vicariously liable on the basis of respondeat superior for the conduct of its employees. ${ }^{83}$ In other words, a city that employs a person who violates an individual's constitutional rights will not be found liable for that wrongdoer's actions. Instead, one can successfully state a claim against a municipality only if the violation of the protected right was caused by (1) a municipal policy, (2) a custom or practice, ${ }^{84}$ or (3) a decision of a final policymaker. $^{85}$

Methods for showing a custom, policy, or practice include demonstrating that an official promulgation is illegal, showing an actual final policymaker ratified the unconstitutional conduct, establishing that a training program was inadequate, or proving that a municipality acquiesced to a custom or policy of a local office. ${ }^{86}$ Essentially, a plaintiff may pursue the full range of damages in a suit against a city, but they must show that there was a formal policy or widespread custom or practice carried out by the city. ${ }^{87}$ The plaintiff may also show that the decision that caused the deprivation was made by a final policymaker, which I discuss further in the next section of this article ${ }^{88}$ Finally, to prove that a municipality is liable, the plaintiff has to show that the municipal policy or decision was the moving force behind the violation. Simply put, there must be a direct causal link between the municipal action and the deprivation. ${ }^{89}$ For this article, understanding who may be a municipal policymaker is therefore particularly important.

81 The Supreme Court has made three landmark decisions around the scope of municipal liability. In Monell v. Department of Social Services, the court recognized that a municipality may be a "person" under the statute, and thus suable. 436 U.S. 658, 690 (1978). In Owen v. City of Independence, the court determined that employees acting in good faith would not create a barrier to receiving damages from the municipality. 445 U.S. 622, 650 (1980). Finally, in City of Newport v. Fact Concerts, the court held that municipalities are absolutely immune from punitive damages in Section 1983 cases. 453 U.S. 247, 271 (1981).

82 Monell, 436 U.S. at 690 ("Our analysis of the legislative history of the Civil Rights Act of 1871 compels the conclusion that Congress did intend municipalities and other local government units to be included among those persons to whom $\S 1983$ applies.").

83 Id. at 691 ("In particular, we conclude that a municipality cannot be held liable solely because it employs a tortfeasor-or, in other words, a municipality cannot be held liable under $\S 1983$ on a respondeat superior theory.").

$84 \quad$ Id. at 694.

85 Id.

86 MASSARON ET AL., supra note 26, at 272-88.; SCHWARTZ, supra note 25, at $§ 7.15$.

87 Monell, 436 U.S. at 690 ("Local governing bodies, therefore, can be sued directly under $\S 1983$ for monetary, declaratory, or injunctive relief where, as here, the action that is alleged to be unconstitutional implements or executes a policy statement, ordinance, regulation, or decision officially adopted and promulgated by that body's officers.").

88 MASSARON ET AL., supra note 26, at 272-88; SCHWARTZ, supra note 25, at $§ 7.15$.

89 City of Canton, Ohio v. Harris, 489 U.S. 378, 385-86 (1989). 


\section{a. Policymakers}

In defining who may be a municipality's final policymaker, the court has considered whether the individual (1) is a state or municipal officer as defined by state and local law and (2) has discretionary or policymaking authority. ${ }^{90}$ If he is defined as a municipal officer and has policymaking authority, then he may be deemed a municipal policymaker. ${ }^{91}$ The court has made clear that determining whether an official is a final policymaker is a question of state, not federal law, and in conducting its analysis, the court's major question should be whether the decisionmaker has final authority to make municipal policy. ${ }^{92}$ Further, determining who is a policymaker is not a question of fact, but law. ${ }^{93}$ In practice, this means that policymaker determinations rely heavily on what the applicable state laws say about the job in question. If a particular state law defines an actor as a state actor, then he cannot be a municipal policymaker, even if in practice, he is working for the municipality.

The most obvious example of a municipal policymaker would be the entity's legislative body, since the local legislature fashions official policy. ${ }^{94} \mathrm{~A}$ more challenging policymaker determination, however, might be the county sheriff who has the discretion to hire an employee but who acts under another county board that sets official county employment policy. ${ }^{95}$ The sheriff may be a final policymaker if the county board delegated its power to him, but he would not be a municipal policymaker if the board iterated the final policy and the sheriff simply followed the handed down policy. ${ }^{96}$ In this example, the court analyzes who is an "official policymaker" according to the law, but it does not consider all of the primary functions the sheriff may perform for the municipality. This example shows how convoluted the "Who is a policymaker?" question can become.

The current state law specific standard may also be limited in that it seems to rely too heavily on formulaic statutory definitions instead of real-world job functions. To illustrate, in McMillian v. Monroe County, the Supreme Court had to determine whether a county sheriff was a county actor or state actor under Alabama state law. ${ }^{97}$ The court reiterated that an inquiry into who qualifies as a local actor is dependent on that official's role as defined by state law. ${ }^{98}$ The Court then went through a lengthy analysis of Alabama's Constitution, the framers' intent regarding sheriffs, and Code sections pertaining to sheriffs. ${ }^{99}$ The court ultimately decided solely based on

$90 \quad$ See City of St. Louis v. Praprotnik, 485 U.S. 112 (1988); Pembaur v. Cincinnati, 475 U.S. 469 (1986); MASSARON ET AL., supra note 26, at 272-88; SCHWARTZ, supra note 25, at $\S 7.15$.

91 See Pembaur, 475 U.S. at 483 n.12 (1986).

92 McMillian v. Monroe County, Alabama, 520 U.S. 781 (1997)

93 See id; MASSARON ET AL., supra note 26, at 272-88; SCHWARTZ, supra note 25, at $\S 7.15$.

94 SCHWARTZ, supra note 25 , at $\S 7.15$.

95 See Pembaur, 475 U.S. at 483 n.12 (Justice Brennan presented this exact scenario and explained that if the Board set final policy, then the Sheriff could not be a final policymaker, but if the Board delegated its own power to the Sheriff to oversee hiring and firing, then the Sheriff could be a final policymaker). See also MASSARON ET AL., supra note 26, at 272-88 and SCHWARTZ, supra note 25 , at $§ 7.15$.
96 See Pembaur, 475 U.S. at 483 n.12.
97520 U.S. at 781.
$98 \quad$ Id. at 786.
$99 \quad$ Id. at $787-91$. 
those documents showing that sheriffs were state actors and not municipal policymakers in Alabama. ${ }^{100}$

On the other hand, the petitioner in McMillian pointed out that Alabama sheriffs were paid by the county, provided with county equipment and lodging, limited in jurisdiction solely to the county, and elected locally by county citizens. These factors, demonstrating the actual local function of the sheriff's job, were not enough to persuade the court that the sheriff was a county policymaker. ${ }^{101}$ So, while the current state law-specific standard lends some predictability to the process of determining who is a policymaker-either an applicable state law defines an individual as a state actor or not-it may, at times, overlook compelling facts that suggest a different result.

Another limitation to the state law-specific analysis is that it can and does produce different results across states. In McMillian, the petitioner argued that the court's approach would result in inconsistent policymaker determinations throughout the country. ${ }^{102}$ The Court rebutted by emphasizing the federal nature of our government: states may organize their localities as they see fit, so it is natural that municipal policymaker determinations differ from state to state. ${ }^{103}$ The Court explicitly rejected a uniform national characterization of sheriffs, calling the approach a "blunderbuss." 104

In effect, the McMillian Court seemed to advance an argument that only two approaches to policymaker determinations exist. On one hand is its preferred approach, the state law analysis; on the other is a system that would uniformly characterize municipal policymakers (or, at least sheriffs, in the instant case). Is there a middle ground approach that considers state law but also engages in an analysis of how an official actually performs their functions in practice? Indeed, the primary goal of this article is to demonstrate that a more functional approach to municipal policymaker determinations may produce more just results in litigation addressing unconstitutional bail, fine, and fee practices.

For this article, the predominant question is whether a municipal judge may also be deemed a final policymaker for purposes of suits brought against them under 42 U.S.C. $§ 1983$. Most courts maintain that judges acting in their official "judicial" capacity cannot be final policymakers. As discussed in the aforementioned sheriff example, this state law-specific inquiry can become an arbitrary test that generates inconsistent results and ignores important facts about the ways in which an official performs their actual function.

$100 I d$. at 793. Here, the Court did consider the sheriff's functions as described by the state law. For example, the Court noted that pursuant to the Alabama Code, the Governor and Attorney General have control over the sheriff when they direct him to conduct an investigation. This shows that there is a small element of considering the policymakers function, but the problem still exists in that such an approach relies only on how the state law defines the role, not how the official is actually conducting himself.

$101 I d$. at 803 (Ginsburg, J., dissenting) (criticizing the state law dependent analysis and stating, "[a] sheriff locally elected, paid and equipped, who autonomously sets and implements law enforcement policies operative within the geographic confines of a county, is ordinarily just what he seems to be: a county official. Nothing in Alabama law warrants a different conclusion. It makes scant sense to treat sheriffs' activities differently based on the presence or absence of state constitutional provisions of the limited kind Alabama has adopted.").

$\begin{array}{ll}102 & \text { Id. at } 793 . \\ 103 & I d . \text { at } 795 . \\ 104 & I d .\end{array}$




\section{b. When a Municipal Judiciary is Influenced by the Local Executive Branch}

The reality that some municipal courts do not function as independently as one would hope further complicates the policymaker analysis. Instead, some municipal judges may be hired and fired by the mayor or city council and carry out their functions subject to potential oversight by the executive and legislative branches. ${ }^{105}$ Further, some municipal financing structures put pressure on local judiciaries to generate revenue so that the court is self-funded. ${ }^{106}$ This demonstrates the interconnectedness of the local executive and "judicial" branches. The judiciary may at times appear to be more of an administrative arm of the executive instead of an independent judiciary. Such an arrangement is ripe for abuse and puts judges in conflicted positions.

For example, in the aftermath of Mike Brown's death in Ferguson, Missouri, the Department of Justice investigated the city and issued a report. ${ }^{107}$ One major finding of the report was that the municipal court of Ferguson had been operating with the end goal of generating revenue, and the interconnectedness of the city's branches undoubtedly played a role. ${ }^{108}$ The report stated, "City, police and court officials for years have worked in concert to maximize revenue at every stage of the enforcement process, beginning with how fines and fine enforcement processes are established." 109 The report goes on to detail numerous egregious instances in which the municipal court violated defendants' constitutional rights to improve the city's bottom line. ${ }^{110}$ Such cases may, in fact, be doubly unconstitutional in that (1) an indigent defendant may have a fine or fee unconstitutionally imposed on them and (2) it is patently unconstitutional for a judge to have significant pecuniary interest in the outcome of a case. ${ }^{111}$

105 See Jordan v. Smith, 669 So. 2 d 752 (Miss. 1996). In Jordan, the mayor of Greenwood was in a dispute with the Greenwood City Council on whether his executive appointments (including the municipal judge appointment) were subject to approval by the City Council. Id. The Mississippi Supreme Court explained, “ . . although the Legislature has specifically defined the council's role as legislative and the mayor's role as executive, the Legislature has also required the two entities to jointly decide on city department directors, members of municipal boards and a plethora of other municipal authorities and commissions, most of which have unquestionably executive functions." Id. at 757. Further, the court stated, "[t]he governing authorities of the City of Greenwood are clearly authorized to appoint a municipal judge and the other officers here involved. See, e. g., Miss. Code Ann. § 21-23-3 (1972). The question here involved is apportionment of responsibility for appointments among the constituent elements of municipal authority. While the city council has no authority to appoint, nothing in our statutes or precedents denies the Council an advice and consent role in the appointive process. In such circumstances, the governing authorities of Greenwood is free to adopt the ordinances here questioned. Miss. Code Ann. $§ 21-17-5$ (1972) ('The governing authorities of every municipality . . . shall have the power to adopt any orders, resolutions or ordinances with respect to municipal affairs ... which are not inconsistent with the Mississippi Constitution of 1890 , the Mississippi Code of 1972, or any statute or law of the State of Mississippi. ...')." Id. In other words, this is an example of how a municipality may have freedom in crafting how it appoints municipal judges. Clearly, in an appointive process like the one Greenwood employed, bright lines between the executive, legislative, and judicial branches may be hard to find.

106 See Cain v. City of New Orleans, 281 F. Supp. 3d 624 (E.D. La. 2017).

107 U.S. DEP'T OF JUSTICE, CIVIL Rights Division, INVESTIGATION OF THE FERGUSON POLICE DEPARTMENT (2015), https://www.justice.gov/sites/default/files/opa/press-releases/attachments/2015/03/04/ferguson_police_department _report.pdf [https://perma.cc/9WZ4-BJV7].
$108 \quad I d$. at 3.
$109 I d$. at 10
110 Id. at 42, 44, 45-46, 48-54, 57, 59-60.
111 Tumey v. State of Ohio, 273 U.S. 510 (1927). 
To illustrate, in Tumey $v$. Ohio, the defendant had been issued a fine for possessing liquor. ${ }^{12}$ The money collected from such fines was put into a pool that was then disbursed between the state and locality. ${ }^{113}$ From this pool, the convicting judge's ${ }^{114}$ salary was paid, and thus, the judge's salary was dependent on the number of convictions issued. ${ }^{115}$ The Supreme Court held that a criminal defendant's due process rights are violated where a judge's service is tied to the rate of conviction. ${ }^{116}$ In other words, due process is violated where the convicting judge has a pecuniary interest in a case over which they preside. ${ }^{117}$ The holding in Tumey thus has been used to justify a grant of declarative relief in modern cases involving unconstitutional bail, fine, and fee practices. ${ }^{118}$

Some courts, then, have recognized the unconstitutionality of pressuring municipal judges into funding their own courts' expenses through the imposition of fines and fees. This recognition demonstrates that there is a point at which the fluidity of decision-making between the local judiciary and the other branches becomes unacceptable. Why, then, allow a responsible municipality to insulate itself from liability in Section 1983 cases involving unconstitutional judicial orders?

\section{ARGUMENT}

\section{A. Recap: Putting the Pieces Together}

Debtors' prisons are unconstitutional, but they still crop up at times in the context of municipal courts' bail, fine, and fee practices. Wronged plaintiffs may pursue damages and injunctive relief pursuant to Section 1983, which was created to give individuals a path to relief when state actors have violated their federally protected rights. Further, Section 1983 operates with the twin aims of giving compensation to injured individuals and deterring constitutional wrongdoers. While the doctrine has been expanded in the past half century, courts also have recognized certain defenses such as absolute and qualified immunity, which can circumvent the compensation and deterrence functions of the law itself.

\footnotetext{
$112 \quad I d$. at 516.

113 Id. at 516-20.

114 Interestingly, the judge in Tumey was also the mayor, which further demonstrates the potential for interconnectedness in local government branches.

115 Tumey, 273 U.S. at 531-32.

116 Id

117 Id.

118 See generally Cain v. City of New Orleans, 281 F. Supp. 3d 624 (E.D. La. 2017). In Cain, plaintiffs sued the city of New Orleans under Section 1983 alleging several violations of their constitutional rights including fines imposed without indigency determinations and a scheme of money bonds that were used to fund certain judicial offices. There was ample evidence that the city court was being funded through a structure that pressured judges into issuing more fines and fees in order to operate the court. The Court found this structure unconstitutional and stated, "[t]his funding structure puts the Judges in the difficult position of not having sufficient funds to staff their offices unless they impose and collect sufficient fines and fees from a largely indigent population of criminal defendants." Id. at 655 . The Court went on to state, "[p]laintiffs have established that the Judges' dual role creates a 'possible temptation . . . not to hold the balance nice, clear, and true between the state and the accused."' Id. The court also noted that the judges' conflict of interest existed by no fault of their own, but through the fault of the city choosing to inadequately fund the court and then placing the judge in the predicament of having to fund court operations.
} 
In the context of municipalities' bail, fine, and fee regimes, the judicial immunity defense poses the most difficult hurdle. The sued municipality may assert that the conduct that caused the constitutional deprivation was a judicial order made by an immune judge who cannot be a municipal policymaker. Essentially, the argument is that money damages are inappropriate because the judge is immune from such a suit, and he is the actor that caused the deprivation. In turn, the argument extends to the municipality, which can claim that the judge is not a municipal policymaker, so the city should not have to pay money damages even if constitutional violations did occur.

Next, arguing that the immune judge is a municipal policymaker that instituted a municipal custom, policy, or practice is often difficult because courts typically hold that a municipal judge is not a policymaker when performing a judicial act. A common result of this conundrum is that plaintiffs cannot receive money damages in cases involving unconstitutional bail, fine, and fee practices. This, in turn, undermines Section 1983's historical policy justifications in favor of compensating victims and deterring wrongdoers. Further, not recognizing the judge as a municipal policymaker can obfuscate the interconnectedness of the executive and judicial branches of government.

To further show how all of these issues converge to form an uphill battle for plaintiffs, consider the following case examples, which demonstrate potential outcomes of the argument that "the judge is a municipal policymaker.". These examples also demonstrate how a local judiciary may act in concert with other city branches, raising important questions about the need to safeguard judicial independence.

\section{B. Case Examples}

\section{Judge Not Recognized as a Policymaker}

In Ray v. Judicial Corrections Services, Inc. an Alabama municipal court judge recommended that the city mayor hire a third-party probation service to oversee the municipal court's probation scheme and fine and fee collections. ${ }^{119}$ The city mayor subsequently entered into a contract with defendant Judicial Corrections Services, Inc. ("JCS"). The municipal judge, by all accounts, did not sign the contract and was not responsible for hiring the service. ${ }^{120}$ Two of the plaintiffs in the case had received, as defendants, minor traffic tickets and had been subsequently ordered to pay fines. ${ }^{121}$ Because they could not afford to do so, the judge referred them to probation with JCS, which required the plaintiffs to pay the fine in installments. ${ }^{122}$ JCS would ultimately come to collect an additional, probation servicing fee, which only extended the plaintiffs' period of indebtedness further. ${ }^{123}$ Because probation violators could be sentenced to time in jail for failure to

119 Ray v. Judicial Corrs. Servs., Inc., 2017 WL 660842 , at *2 (N.D. Ala. Feb. 17, 2017).
120 Id.
121 Id. at *8-9.
122 See id. at *2-3, *22 (“According to Plaintiffs, the City's 'practice and policy' treated poor people less favorably than wealthier people because Municipal Court defendants who were able to pay the imposed fines and costs did not face the additional burden of probation under JCS's supervision, whereas defendants who were unable to pay those fines and costs were placed on probation, charged additional fees, and subjected to threats of incarceration.").

123

Id. 
meet their payment obligations, ${ }^{124}$ the two traffic violators were arrested after violating the judge's order that they satisfy their debt during twenty-four months of probation. ${ }^{125}$ As a result of his arrest, one plaintiff was required to come up with over $\$ 500$ to meet bail. ${ }^{126}$

When the Ray plaintiffs subsequently filed a Section 1983 claim against the city, the court determined that they had not successfully shown that a municipal policy or custom existed, since their claims stemmed from "judicial," and not "municipal," acts. ${ }^{127}$ Further, when conducting the policymaker analysis, the court found that officers of the municipal court were state officials (not municipal policymakers), and thus, the city could not be liable for the unconstitutional judicial practices. $^{128}$

The Ray case reveals the ways in which it might be plainly unreasonable, and deficient as a matter of fairness, to afford judges in this context any sort of immunity. For one, the municipality clearly sanctioned the Ray judge's behavior and that of JCS by agreeing to contract with the probation services company in the first place. Implicit in that agreement was a desire on the municipality's part to increase revenue - and JCS touted its ability to achieve as much on its website. ${ }^{129}$ One of its claims included the guarantee that JCS's " . . supervision of probationers was 'completely offender-funded' with no expense to taxpayers, and that '[c]ourt collections have increased in every community that has made the transition to JCS." 130 The municipality thus worked alongside JCS to help the Ray judge promulgate an extortionate probationary scheme that negatively affected indigent defendants.

Second, because the court relied on state statutory language defining municipal judges as state actors, no real consideration of the judge's actual position within the city was made. A more fact-intensive inquiry might have revealed both the local nature of the municipal judge's role and the pressure that the executive was putting on the judiciary to generate revenue. A more functional analysis with fact specific inquiries might also have demonstrated that the municipal judge in this case was a state actor in name only, and a finding that he acted as a municipal policymaker when he issued the judicial decree in Ray would have been justified.

The municipality in Ray, however, was able to insulate itself from liability by hiding beneath the judge's robes and claiming, matter-of-factly, that he could not be a municipal policymaker. By extension the municipality was able to fend off claims of constitutional deprivation, despite its having pressured the judge to fund his court and its direct hiring of JCS. And

$\begin{array}{ll}124 & I d . \text { at } * 2, * 13 . \\ 125 & I d . \text { at } * 8-9 . \\ 126 & I d . \\ 127 & I d . \text { at } * 31 . \\ 128 & I d . \text { at } * 9, * 25-31 .\end{array}$

129 Human Rights Watch, Profiting From Probation: AmERiCA’s “OFFENDER-FundeD” Probation INDUSTRY (Feb. 5, 2014) [hereinafter, "HUMAN RIGHTS WATCH WEBSITE"] (quoting Judicial Correction Services, "For the Community," undated, http://judicialservices.com/what-we-provide/for-the-community/), https://www.hrw.org/report/ 2014/02/05/profiting-probation/americas-offender-funded-probation-industry [https://perma.cc/C3U3-R4XF]. See also Judge T. Brad Bishop \& Laura E. Yetter, The Continuing Reformation of Alabama's Municipal Courts, 79 ALA. LAWYER 191, 193 (2018) (citing HUMAN RIGHTS WATCH WEBSITE) ("JCS guaranteed that its supervision of probationers was 'completely offender-funded' with no expense to taxpayers, and that '[c]ourt collections have increased in every community that has made the transition to JCS' ... [p]rivate probation companies like JCS that operate on an 'offender-funded' basis require probationers to pay the entire costs of probation services rendered."). 
for the numerous indigent individuals who sat in jail cells over fines associated with minor offenses like traffic violations? The policymaker determination in this case effectively denied them a chance to secure monetary relief. ${ }^{131}$

\section{Judge Recognized as Policymaker}

As aforementioned, one way to combat an immunity defense in these cases is to argue that the judge is in fact a policymaker, though, as this article has demonstrated, such an argument is not likely to succeed. A recent Fifth Circuit case, Odonnell v. Harris County, is also illustrative. ${ }^{132}$ The plaintiff sued the county, the county judge, the sheriff, and other county officials for their practice of setting bail, which resulted in the detention of indigent defendants without consideration of their ability to pay. ${ }^{133}$ Contrary to many court findings, ${ }^{134}$ the Fifth Circuit found that the county judge in Odonnell was acting as a final policymaker under Section 1983 and thus, the county could be liable for his decisions. ${ }^{135}$

In its reasoning, the Odonnell court employed a formulaic analysis of pertinent Section 1983 decisions. ${ }^{136}$ The judge was considered a county policymaker only because the Texas State Constitution defined a county judge as a "county officer" and not as a state officer. ${ }^{137}$ The court in

131 See, e.g., Cunningham ex rel. Cunningham v. City of W. Point Miss., 380 F. App’x 419, 421-22 (5th Cir. 2010) (affirming the district court's decision that "there was no valid policymaker on whom the City's alleged $\S 1983$ municipal liability could be pinned.”); Garcia Guevara v. City of Haltom City, 106 F. App'x 900, 902 (5th Cir. 2004) (declining to find liability because "[t]he relevant decisions were made, not by a City policymaker, but by a municipal judge acting in his judicial capacity.”); Whisenant v. City of Haltom City, 106 F. App’x 915, 917 (5th Cir. 2004) (holding that the city could not be held liable for a judge acting as a state judicial officer, but could on behalf of the city council as a policymaking entity); Eggar v. City of Livingston, 40 F.3d 312, 315 (9th Cir. 1994) (“[T]he Judge's obligation to address the rights of defendants arises from his membership in the state judiciary. It is lamentable, but irrelevant, that he failed miserably to meet this obligation under both state and federal standards: he simply is not a municipal decision maker in this context.”); Johnson v. Moore, 958 F.2d 92, 94 (5th Cir. 1992) (finding a municipal judge's repeated decision to jail an indigent without offering counsel could not demonstrate a municipal policy in order to establish municipal liability); Bigford v. Taylor, 834 F.2d 1213, 1223 (5th Cir. 1988) ("Finally, although Bigford presented some evidence that Sheriff Taylor was aware of the delay in returning the truck and did nothing to resolve it, the sheriff was not the county's policymaker as to such judicial matters, as opposed to law enforcement matters. There is no evidence that the county's governing body or other high officials approved or were even aware of the magistrate's failure to act.").

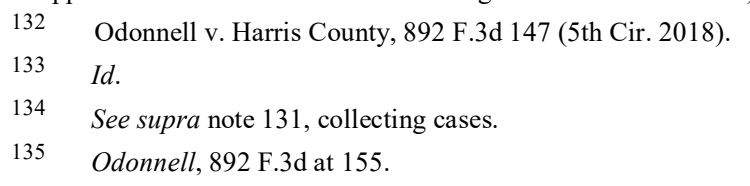

136 Id. ("Liability under Section 1983 attaches to local government officers 'whose unlawful decisions represent the official policy of the governmental unit.' Whether an officer has been given this authority is 'a question of state law.' 'Official policy' includes unwritten widespread practices that are 'so common and well settled as to constitute a custom that fairly represents municipal policy.' And unlawful decisions include 'acquiescence in a longstanding practice or custom which constitutes the standard operating procedure of the local governmental entity." (internal citations omitted) (first quoting Jett v. Dallas Independent School District, 491 U.S. 701, 737 (1989); then quoting Pembaur v. City of Cincinnati, 475 U.S. 469 (1986); and then quoting Johnson v. Moore, 958 F.2d 92, 94 (5th Cir. 1992)).

137 Id. ("Though a judge is not liable when 'acting in his or her judicial capacity to enforce state law,' we agree with the district court that County Judges are policymakers for the municipality. Texas law explicitly establishes that the Judges are 'county officers."” (quoting Johnson v. Moore, 958 F.2d 92, 94 (5th Cir. 1992); and then quoting Tex. Const. 
Ray adopted a similar approach, only to determine that the judge there was not a municipal policymaker because Alabama's code did not define municipal judges as local officers. Evidently, then, courts' reliance on local statutory and constitutional language, without further consideration of how a municipality and its actors actually function, results in arbitrary holdings in Section 1983 litigation. ${ }^{138}$ Further, it may leave wronged plaintiffs without a clear path to holding a municipality liable for the actions of a judge acting in his municipal capacity.

\section{A Better Solution? A Functional Approach}

The disparate holdings of Ray and Odonnell suggest a need to locate a more balanced approach for courts whereby they rely less heavily on statutory language and more seriously assess the judge's actual role within the municipality. Such an approach might be helpful to plaintiffs asserting constitutional deprivation. Instead of engaging in a myopic analysis that generates inconsistent results, why not take a more functional approach to determining whether a judge is a municipal policymaker? The proposition is this-for municipal policymaker determinations, an assessment of the facts surrounding a particular judge's actual function should augment a court's review of local statutes and constitutions.

\section{Description}

Courts should take a functional approach to determining whether a judge is a municipal policymaker where plaintiffs assert Section 1983 claims that rest on a pattern of unconstitutional judicial practices in a municipality. This functional analysis would not affect the municipal judge's individual immunity; instead, it would simply draw a line connecting the judge's unconstitutional actions to the municipality's employment of that judge and, by extension, its complicity in allowing such custom, policy, or practice to develop.

A functional approach, rather than a formulaic one, could also be useful in shedding light on the tangled web that municipal governments may resemble. Often, mayors have the power to hire and fire these judges, set judicial salaries, and define judges' roles. This type of executive oversight makes the municipal judge function as more of an executive officer. A functional approach would consider the individual judge's actual role and duties within the municipality and would uncover instances in which the municipality placed undue pressure on the judge to collect fines and fees. A more functional approach would demonstrate when a municipality was actually

\footnotetext{
Art. V § 24)); see also West v. City of Santa Fe, Texas, No. 3:16-CV-0309, 2018 WL 4047115, at *7 (S.D. Tex. Aug. 16, 2018) ("The Fifth Circuit recently held in Odonnell that county court at law judges are municipal policymakers for postarrest practices in light of their 'broad authority to promulgate rules that will dictate post-arrest policies consistent with the provisions of state law."').

138 Also, consider the Supreme Court's analysis of whether a sheriff was a municipal policymaker in McMillian. McMillian v. Monroe County, Ala., 520 U.S. 781, 786-88 (1997). While constitutional and statutory definitions played the central role in the analysis, the court did at least consider how the state law described the official's functions. Lower court cases, on the other hand, seem to shy away from engaging in a robust analysis of all the relevant constitutional and statutory provisions. In Odonnell, for example, the Fifth Circuit's analysis was limited solely to a two-word definition in the Texas Constitution. Odonnell, 892 F.3d at 155 ("Texas law explicitly established that the Judges are "county officers'...." (quoting TEX. CONST. art. V § 24)). Lower courts, then, seem to be taking a less thorough approach by identifying some type of state law that defines the actor as either state or local and stopping there in the analysis.
} 
complicit in allowing unconstitutional bail, fine, and fee arrangements to persist. The responsible municipality, then - and not the judge - could be held liable, and wronged plaintiffs could recover the damages they deserve. This functional approach would not actually affect the individual judge's immunity from liability, and more significantly, would be consistent with Section 1983's goals of compensation and deterrence.

\section{Other Areas of Section 1983 Litigation that Employ a Functional Approach}

Further, the argument for a functional analysis when considering whether a municipal judge is a policymaker is not a novel one. Other areas of Section 1983 litigation already employ a functional analysis. Take, for example, determinations of immunity. When determining whether an officer should receive absolute immunity, qualified immunity, or no immunity, courts look to the facts of the situation and the actual role that the officer was performing - not some formulaic definition of the officer's job as contained in a local statute or constitution. ${ }^{139}$ The Court has maintained that a determination of immunity is made according to functionality and not job title. ${ }^{140}$

To illustrate, in Forrester $v$. White the Supreme Court had to determine whether a judge was entitled to absolute immunity in a suit where a former court employee sued the judge for discharging her in violation of the Equal Protection Clause. ${ }^{141}$ The court reiterated that an analysis of whether the function in question was judicial or adjudicative was essential to determining whether the judge was entitled to absolute immunity. ${ }^{142}$ The Court conducted an analysis of the judge's actions to find that, in firing the employee, the judge was acting in an administrative capacity, rather than a judicial one. ${ }^{143}$ The court did not simply rely on a statutory definition of "judge" and thereby grant absolute immunity. Instead, the court noted that non-adjudicative functions, like hiring and firing, did not require immunity and even likened the judge's actions to those of executive branch officials. ${ }^{144}$ The important concept to note here is not that the judge ultimately did not receive immunity; it's that the court made a fact-specific inquiry into the judge's actual function. ${ }^{145}$

139 SCHWARTZ, supra note 25 , at $\$ 9.02(\mathrm{~B})$.

140 In discussing whether a judge should receive immunity or not, the court explained, "[d]ifficulties have arisen primarily in attempting to draw the line between truly judicial acts, for which immunity is appropriate, and acts that simply happen to have been done by judges. Here, as in other contexts, immunity is justified and defined by the functions it protects and serves, not by the person to whom it attaches." Forrester v. White, 484 U.S. 219, 227 (1988).

141 Forrester, 484 U.S. at 220 (1988).

$142 \quad I d$. at 229.

143 Id. at 229-30.

$144 I d$. at 229 ("In the case before us, we think it clear that Judge White was acting in an administrative capacity when he demoted and discharged Forrester. Those acts-like many others involved in supervising court employees and overseeing the efficient operation of a court-may have been quite important in providing the sound adjudicative system. The decisions at issue, however, were not themselves judicial or adjudicative. As Judge Posner pointed out below, a judge who hires or fires a probation officer cannot meaningfully be distinguished from a district attorney who hires and fires assistant district attorneys, or indeed from any other Executive Branch official who is responsible for making such employment decisions. Such decisions, like personnel decisions made by judges, are often crucial to the efficient operation of public institutions ... yet no one suggests that they give rise to absolute immunity from liability in damages under Section 1983.").

145 For other Supreme Court cases where the Justices employed the functional approach in making immunity 
Theoretically, in making policymaker determinations, courts could employ a similar factspecific, situation-dependent analysis. Instead of relying on statutory definitions of whether a judge is a state or local official, courts could look at how the judge is actually functioning. For example, in $R a y,{ }^{146}$ this functional analysis may have revealed that the municipal judge was acting for the city - not as a part of larger state judiciary. A functional approach might have led to a conclusion that the judge in Ray was functioning as an arm of the city due to the pressure it placed on him to collect more fines and fees. The judge's delegation of probation oversight to JCS could be viewed as a policy decision made by the local judge and mayor in tandem. A consideration of the facts on the ground would demonstrate that the judge was not functioning as an independent part of the state judiciary but as an integral part of the local government, and for that reason, a determination that he was a municipal policymaker would have been appropriate. In turn, the responsible city could have been liable for money damages for the unconstitutional probationary practices.

A more functional approach also crops up in Eleventh Amendment immunity determinations. Courts take into account different factors when determining whether an entity is a state or municipal entity for Eleventh Amendment immunity purposes. ${ }^{147}$ Courts may consider whether the entity is engaging in a function for the state or local government, the source of funding, and whether the entity is subject to state control. ${ }^{148}$ Using these factors, a court would be more likely to discern the true nature of the relationship between a judge and a municipality. In turn, a determination that a judge is in fact a municipal policymaker instead of a state actor might be more readily revealed. Instead of only relying on a rote definition, courts could consider a variety of factors when considering whether an entity is state or local. This same kind of logic should be employed in making policymaker determinations. There are, however, limitations to a functional approach.

\section{Limitations to a Functional Approach}

First, a functional approach in policymaker determinations may be criticized in that it adds an extra layer of analysis to the current one. Currently, courts can look to a state's constitution or code, and if a judge is defined as part of a larger state judiciary, then he cannot be a municipal policymaker. That type of definition would end the policymaker analysis, and the municipality would be off the hook.

On the other hand, if the state constitution or code defined the judge as a "local actor," then he could be a policymaker, thereby bringing a swift end to the policymaker analysis. The point is that the current statutory policymaker analysis lends ease to policymaker determinations. There is no need to dig further into the judge's day-to-day actions and interactions with the other local government branches. To employ a functional approach would add an extra layer of complexity, though it arguably would give plaintiffs more fair, consistent results from state to state.

Another argument against employing a functional approach to policymaker determinations

\footnotetext{
determinations, see Buckley v. Fitzsimmons, 509 U.S. 259 (1993), Burns v. Reed, 500 U.S. 478 (1991), and Cleavinger v. Saxner, 474 U.S. 193 (1985).

146 Ray v. Judicial Corrs. Servs., Inc., 2017 WL 660842 (N.D. Ala. Feb. 17, 2017).

147 See Ainsworth Aristocrat Int'l Party v. Tourism Co., 818 F.2d 1034, 1038 (1st Cir. 1987) (“The decision whether a state institution or entity is an arm of the state for Eleventh Amendment immunity purposes should not be made without a full examination of all the factors.”); SCHWARTZ, supra note 25, at $\S 8.10(\mathrm{D})(1)$.

148

Id.
} 
is that there may be less dramatic ways for plaintiffs to pursue money damages against a municipality. For example, one potential route around the "judge as a policymaker" conundrum is to make a claim against a municipal actor other than a judge. For example, a plaintiff could make the policymaker claim against a court clerk that collects fees or the probation service that oversees fine and fee collecting.

To illustrate, in Luse v. Sentinel Offender Services, a class action was filed against a Georgia probation service by two women who had been put on probation while they paid off traffic violation fines. ${ }^{149}$ Sentinel, the probation service, would require the plaintiffs to pay for drug tests even though that was not a condition of their probation. ${ }^{150}$ If the defendants did not comply, they were threatened with immediate incarceration. ${ }^{151}$ Instead of suing the municipality based on the judge's original order, these plaintiffs sued the probation service under Section 1983 for creating unconstitutional policies and practices in performing their probationary duties. ${ }^{152}$ Based on these circumstances, the defendants entered into a settlement agreement which included injunctive relief, a consent order, and an $\$ 80,000$ pool for plaintiffs to recover some of the money spent on the unnecessary drug tests. ${ }^{153}$

This case demonstrates that with creative pleading, plaintiffs may have a chance at receiving money damages without a "judge as a policymaker" analysis standing in their way. In other words, instead of changing the way that a court defines policymakers, plaintiffs may attempt to make a different type of claim in order to receive the money damages they deserve.

\section{CONCLUSION}

In sum, a functional approach to making policymaker determinations is not without its shortcomings. Altering the current analysis in favor of a functional analysis complicates the process, and there may be less drastic avenues for plaintiffs to pursue when attempting to get money damages. On the other hand, Section 1983 was created for the purposes of compensating those deprived of their rights and deterring prospective wrongdoers. The current policymaker analysis accomplishes neither goal in the context of municipal liability for unconstitutional bail, fine, and fee practices. Instead, courts choose a simpler route and look to a how state law defines a judge without actually considering how a local judge may be carrying out a city's policies through judicial orders.

149 Luse v. Sentinel Offender Services, 2:16-cv-00030-RWS (N.D. Ga. 2017), https://www.clearinghouse.net/detail.php?id=15184 [https://perma.cc/24WY-AGSM] (on file with the University of Michigan Law School); see also Complaint at 1-2, Luse v. Sentinel Offender Services, 2:16-cv-00030-RWS (N.D. Ga. Feb. 17, 2016), https://www.clearinghouse.net/chDocs/public/CJ-GA-0013-0001.pdf [https://perma.cc/3T7Y-3GXZ].

150 Complaint at 13, 16, Luse v. Sentinel Offender Services, 2:16-cv-00030-RWS (N.D. Ga. Feb. 17, 2016); Amended Complaint at 2, Luse v. Sentinel Offender Services, 2:16-cv-00030-RWS (N.D. Ga. April 1, 2016), https://www.clearinghouse.net/chDocs/public/CJ-GA-0013-0002.pdf [https://perma.cc/CJ5X-3FHG].

151 Complaint at 5, Luse v. Sentinel Offender Services, 2:16-cv-00030-RWS (N.D. Ga. Feb. 17, 2016).

152 Amended Complaint at 20-24, Luse v. Sentinel Offender Services, 2:16-cv-00030-RWS (N.D. Ga. April

$1,2016)$.

153 See Settlement Agreement, Luse v. Sentinel Offender Services, 2:16-cv-00030-RWS (N.D. Ga. Aug. 21, 2017), https://www.clearinghouse.net/chDocs/public/CJ-GA-0013-0004.pdf [https://perma.cc/S9HU-TV94]; Consent Order, Luse v. Sentinel Offender Services, 2:16-cv-00030-RWS (N.D. Ga. Aug. 14, 2017), https://www.clearinghouse.net/chDocs/public/CJ-GA-0013-0003.pdf [https://perma.cc/2J6T-JF3F]. 
Given that a consideration of all facts could be made, a functional approach would uncover those instances in which a judge is acting as an arm of the city to impose fines and fees in order to raise revenue. In such cases, the municipality should have to pay money damages to plaintiffs who have suffered due to the city's goal of improving its bottom line through its judges. The municipality should not be able to escape liability by simply raising the defense that a judge is independent. Thus, a city complicit in setting up an unconstitutional regime of bail, fines, and fees would be more likely to face liability under a functional approach to policymaker determinations. This, in turn, would ultimately better serve the compensation and deterrence values of Section 1983 by providing plaintiffs a viable route to pursuing money damages. 